\title{
The predictive value of red cell distribution width levels on mortality in intensive care patients with community-acquired intra-abdominal sepsis
}

\author{
Hatice Kaya Özdoğan, M.D.,, ${ }^{1}$ Faruk Karateke, M.D., ${ }^{2}$ Sefa Özyazıcı, M.D., ${ }^{2}$ Mehmet Özdoğan, M.D., ${ }^{3}$ \\ Pınar Özaltun, M.D., ${ }^{4}$ Adnan Kuvvetli, M.D., ${ }^{2}$ Cihan Gökler, M.D., ${ }^{2}$ Zeynep Ersoy, M.D. ${ }^{1}$
}

\author{
1Department of Anesthesia and Reanimation, Adana Numune Training and Research Hospital, Adana \\ ${ }^{2}$ Department of General Surgery, Adana Numune Training and Research Hospital, Adana \\ ${ }^{3}$ Department of General Surgery, Medical Park Hospital, Adana \\ ${ }^{4}$ Department of Biostatistics, Cukurova University Faculty of Medicine, Adana
}

\begin{abstract}
BACKGROUND: Red cell distribution width (RDW) is a part of the complete blood count (CBC) panel reflecting quantitative measure of variability in the size of circulating red blood cells. It has been known that higher RDW is associated with increased mortality in several diseases. The aim of this study was to investigate the association between RDW and hospital mortality in intensive care unit (ICU) patients with community-acquired intra-abdominal sepsis (C-IAS).
\end{abstract}

METHODS: A retrospective analysis of the patients with C-IAS was performed between January I, 20I0 and March $31,2013$. Patients' demographics, co-morbidities, laboratory measures including RDW on admission to the ICU, and Acute Physiologic and Chronic Health Evaluation II (APACHE II) score were analyzed.

RESULTS: A total of one hundred and three patients with C-IAS were included into the study with a mean age of $64 \pm 14$ years. Overall mortality was $50.5 \%$. RDW day I (RDWI) values and APACHE II scores were significantly higher in non-survivors than in survivors. In multivariate analysis, only RDWI and APACHE II predicted mortality. The area under the receiver operating curves (AUC) of RDWI and APACHE II were $0.867(95 \% \mathrm{Cl}, 0.79 \mathrm{I}-0.942)$ and 0.943 (95\% Cl, 0.902-0.984), respectively.

CONCLUSION: This study suggests that increased RDW is associated with mortality in ICU patients with C-IAS.

Keywords: Intensive care unit; intra-abdominal sepsis; mortality; peritonitis; red cell distribution width.

\section{INTRODUCTION}

Intra-abdominal sepsis (IAS) remains a major challenge in clinical practice. Despite the availability of modern and advanced imaging techniques, broad-spectrum antibiotics, and modern intensive care, the mortality rate of patients with IAS is still unacceptably high. ${ }^{[1]}$ The early prediction of patients with greater risk of mortality would allow more aggressive

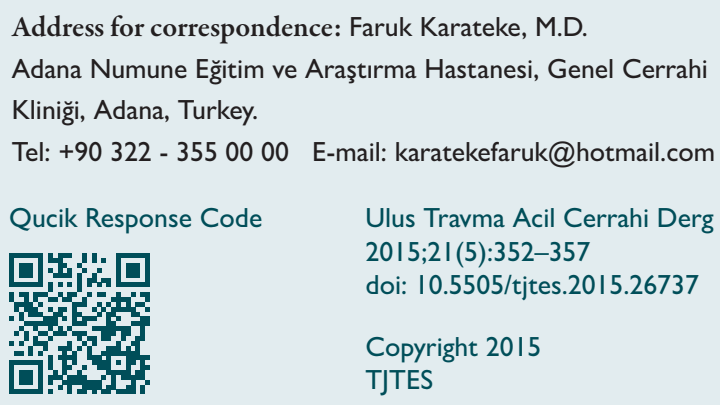

interventions or utilization of novel medical treatment options that could decrease mortality rates.

Red cell distribution width (RDW) is a quantitative measure of variability in the size of circulating red blood cells, and is a part of the complete blood count (CBC) panel. It is mainly used as a tool for the differential diagnosis of anemia and can be found to be elevated in several diseases in which reticulocytes are released into circulation. ${ }^{[2]}$ Furthermore, recent studies have reported that RDW is a novel and interesting prognostic factor in a wide range of clinical manifestations such as critically ill intensive care patients, those with cardiovascular diseases, and even in trauma patients and patients with sepsis/septic shock. ${ }^{[2-5]}$

The pathophysiology of the elevation of RDW in these patients is not well known, but it has been reported that elevated RDW is associated with inflammatory markers such as C-reactive protein (CRP), erythrocyte sedimentation 
rate, interleukin-6 and tumor necrosis factor-alpha. Proinflammatory cytokines of sepsis have been shown to suppress the maturation of red blood cells (RBC) and decrease the half-life of RBCs, resulting in the elevation of RDW values. ${ }^{[2,6]}$

Several biomarkers and various scoring systems have been used to predict the mortality rate in intensive care unit (ICU) patients with peritonitis. To our knowledge, this is the first study reporting RDW as a predictor of mortality in critically ill patients with C-IAS. The primary aim of this study was to determine the association between RDW and hospital mortality in ICU patients with C-IAS.

\section{MATERIALS AND METHODS}

We performed a retrospective analysis of prospectively collected patients' data older than 18 years of agewith C-IAS admitted to ICU of Adana Numune Training and Research Hospital between January I, 2010 and March 31, 2013. The institutional review board approved the study (Ethic committee number:ANEAH.EK.20I3/4I).

C-IAS diagnosis was based on the presence of intra-abdominal infection and sepsis. ${ }^{[7]}$ Diagnosis of sepsis was based on the International Consensus Criteria which has defined sepsis as "the clinical syndrome defined by the presence of both infection and a systemic inflammatory response." ${ }^{[8]}$ All patients were managed following "Surviving Sepsis Campaign: international guidelines for management of severe sepsis and septic shock: 2012. ${ }^{[9]}$ Appropriate antibiotic regime was administered to all patients according to current guidelines or to specific bacterial isolates. Patients with chronic renal failure, malignancy, acute pancreatitis, pregnancy and trauma were excluded from the study. Patients who had required RBC transfusions anytime or any other renal replacement therapy after the admission to ICU were also excluded. In addition, patients who required secondary operations were not included into the study population.

\section{Laboratory Measurements}

The following laboratory measures were obtained from each patient at the time of ICU admission: CBC testing (Roche, SYSMEX, XE, 2l00) including hemoglobin (Hgb), hematocrit (Htc), RDW (reference range, II.0-16.0\%), platelet count (Plt), and white blood cell count (WBC). In addition, serum chemistry including C-reactive protein (CRP), creatinine, blood urea nitrogen, and other blood tests like arterial and venous blood gas analysis (partial pressure of oxygen, $\mathrm{pH}$, and base excess) were noted. Daily RDW measurements were performed during the first seven days after admission to ICU.

\section{Statistical Analysis}

All analyses were performed using SPSS 20.0 (SPSS Inc, Chicago, IL, USA). Continuous variables were presented as mean
( $\pm S D$ ) or median (min-max) for abnormal distributions, and categorical variables were presented as frequencies (\%). Comparisons in the distributions of demographical characteristics, the patients with survivor and non-survivor were evaluated using Student's t-test or Mann-Whitney $U$ test for continuous variables depending on their Gaussian distribution and chi-square test for categorical variables. Variables on admission found to be significant in a univariate analysis were entered into multivariate logistic regression analysis. The prognostic performance of RDW day I (RDWI) and APACHE II score were analyzed using receiver operating characteristic curves (ROC), and calculated sensitivity, specificity, positive predictive value (PPV) and negative predictive value (NPV) using different cut-off values. In addition, patients were allocated into higher RDW group $(\geq 16)$ and normal group $(<16)$, and similarly higher APACHE II score group $(\geq 15)$ and lower score group $(<15)$. Student's-t tests were used to compare mean RDWI, day 3, and day 7 values of survivors and non-survivors. Survival curves were designed using the Kaplan-Meier method, and comparisons were made using the log-rank test. The primary analyses of RDWI and APACHE II association with hospital mortality used sex-specific Cox regression analysis adjusted calculate hazard ratios (HRs) and 95\% confidence intervals (Cls). All tests for differences were considered statistically significant with the two-sided $\mathrm{p}<0.05$ level.

\section{RESULTS}

A total of one hundred and three patients with C-IAS were included into the study with a mean age of $64 \pm 14$ years. Nonsurvivors were older and had more comorbidities. The most frequent source of C-IAS was gastrointestinal tract both in

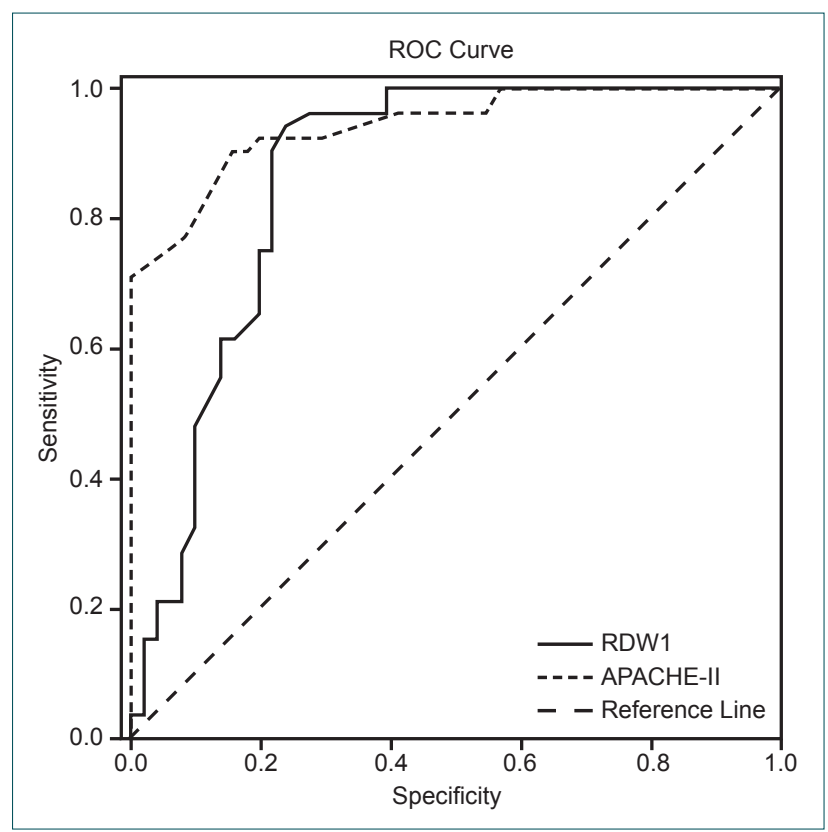

Figure 1. Receiver operating characteristics of RDW1 and APACHE II. 
Table I. Demographics, laboratory and clinical parameters of the patients with C-IAS

\begin{tabular}{|c|c|c|c|c|}
\hline Parameters & $\begin{array}{l}\text { Survivors } \\
(n=5 I)\end{array}$ & $\begin{array}{l}\text { Non-survivors } \\
\quad(n=52)\end{array}$ & $\begin{array}{c}\text { Univariate } \\
\mathbf{p}\end{array}$ & $\begin{array}{c}\text { Multivariate } \\
\mathbf{p}\end{array}$ \\
\hline \multirow[t]{2}{*}{ Age } & $60.2 \pm 14.5$ & $67.8 \pm 12.6$ & 0.005 & NS \\
\hline & $60.0(23-85)$ & $70.0(24-90)$ & & \\
\hline Sex (Male/Female) & $25 / 26$ & $30 / 22$ & NS & \\
\hline \multicolumn{5}{|l|}{ Source of C-IAS, n (\%) } \\
\hline Gastrointestinal tract & $38(74.5)$ & $47(90.4)$ & 0.025 & \\
\hline Hepatobiliary & $13(25.5)$ & $5(9.6)$ & & \\
\hline Comorbidity & $22 / 29$ & $43 / 9$ & 0.0001 & NS \\
\hline \multirow[t]{2}{*}{ Red cell distribution width day I (\%) } & $15.2 \pm 1.9$ & $17.9 \pm 1.8$ & 0.001 & 0.009 \\
\hline & | $4.8(|2.4-2| .7)$ & I7.4 (I5.3-24.0) & & \\
\hline \multirow[t]{2}{*}{ White blood cell count (per $\mathrm{mm}^{3}$ ) } & $13.8 \pm 4.7$ & $18.0 \pm 7.5$ & 0.001 & NS \\
\hline & $14.6(4.3-23.0)$ & I7.5 (4.4-4I.0) & & \\
\hline \multirow[t]{2}{*}{ Hematocrit (\%) } & $34.6 \pm 5.2$ & $32.8 \pm 5.7$ & NS & \\
\hline & $35.0(23.0-45.0)$ & $32.0(23.0-50.0)$ & & \\
\hline \multirow[t]{2}{*}{ Platelet (per mm³) } & $221.1 \pm 98.2$ & $220.6 \pm 99.2$ & NS & \\
\hline & $200.0(83.0-450.0)$ & $207.0(88.0-477.0)$ & & \\
\hline \multirow[t]{2}{*}{ APACHE-II } & $9.4 \pm 5.1$ & $20.5 \pm 4.5$ & 0.0001 & 0.004 \\
\hline & $9.0(1.0-18.0)$ & $20.5(8.0-29.0)$ & & \\
\hline \multirow[t]{2}{*}{ C-reactive protein } & $14.9 \pm 12.0$ & $45.8 \pm 43.3$ & 0.0001 & NS \\
\hline & $\mid 3.0(0.5-5 \mid .0)$ & $39.0(4.7-236.0)$ & & \\
\hline \multirow[t]{2}{*}{ Length of Hospital stay } & $13.7 \pm 8.2$ & $7.8 \pm 5.6$ & 0.0001 & NS \\
\hline & $10(6-45)$ & $7(2-32)$ & & \\
\hline
\end{tabular}

Data are presented as mean \pm SD/median value (interquartile range); SD: Standard deviation; C-IAS: Community-acquired Intra-abdominal sepsis.

survivors and non-survivors. Median length of hospital stay was 7 (I-45) days. Fifty two patients died during hospital stay. In the non-survivor group, RDWI values and APACHE II scores were significantly higher compared to those of the survivors $(p<0.001)$. Demographic, clinical, and laboratory characteristics of survivors and non-survivors are shown in Table I.

Several risk factors on admission that predicted mortality in the univariate analysis (age, source of sepsis, comorbidity, WBC, CRP, RDWI, APACHE II and length of hospital stay) were entered into the multivariate analysis. In the multivariate analysis, RDWI and APACHE II were found to be the only admission variables that predicted mortality (Table I).

Receiver operating characteristic curves of RDWI levels and APACHE II scores were used to identify non-survivors on a statistically significant level (AUC of $0.867 ; 95 \% \mathrm{Cl}, 0.791-$ 0.942 , and AUC of $0.943 ; 95 \% \mathrm{Cl}, 0.902-0.984$, respectively) (Fig. I). PPV and NPV of RDWI and APACHE II were further analyzed. With a cut-off value of 16 for RDWI and cut-off value of 15 for APACHE II, mortality could be predicted in approximately $80 \%$ and $85 \%$ of cases, respectively (Table 2 ).
RDW values were also compared based on hospital mortality. On day I, survivors showed significantly lower levels of RDW than those who died. Comparison of RDWs on days 3 and 7also showed significantly lower levels of RDW in those patients who survived (Table 3).

Kaplan-Meier curve with log-rank test based on sex-specific mortality is shown in Figure 2. RDWI, APACHE II had strong association with mortality for both male and female patients (I5.2\%, 9.4\%; log-rank $p<0.00 \mathrm{I}$, and $25.0 \%, 21.7 \%$ log-rank $\mathrm{p}<0.00 \mathrm{I}$, respectively). Cox proportional hazards analysis predicted mortality in male patients according to high RDW levels (perl\% increase, HR I.07; 95\% Cl, 0.92-1.25; $\mathrm{p}<0.00$ I) and APACHE II scores (per I point increase, HR of I.12; $95 \% \mathrm{Cl}, 1.05-1.19 ; \mathrm{p}<0.00 \mathrm{I}$ ). Similarly, RDWI and APACHE II predicted mortality in female patients (per I\% increase, HR I.20; $95 \% \mathrm{Cl}, 0.95-1.54 ; \mathrm{p}<0.00 \mathrm{I}$ and per I point increase, HR I.22; $95 \% \mathrm{Cl} \mathrm{I.II-I.34;} \mathrm{p}<0.0$ I, respectively).

There were significant positive correlations between RDWI values and age $(r=0.20 p<0.05)$, WBC $(r=0.26 p<0.01)$, APACHE II $(r=0.56 p<0.0 I)$ and CRP $(r=0.48 p<0.0 I)$. In contrast, RDWI values were negatively correlated with $\mathrm{Htc}(r=-$ 
Table 2. Sensitivity, specificity, LR+ and LR-, PPV, and NPV of RDWI and APACHE II. 95\% CI were given in parenthesis

\begin{tabular}{lcccccc}
\hline Variable & Sensitivity & Specificity & LR+ & LR- & PPV & NPV \\
\hline RDWI $\geq 16$ & $94.23 \%$ & $76.47 \%$ & 4.00 & 0.08 & $80.33 \%$ & $92.86 \%$ \\
& $(84.03-98.73)$ & $(62.50-87.20)$ & $(2.43-6.60)$ & $(0.02-0.23)$ & $(68.15-89.39)$ & $(80.49-98.42)$ \\
APACHE II $\geq 15$ & $90.38 \%$ & 84.31 & 5.76 & 0.11 & $85.45 \%$ & $89.58 \%$ \\
& $(78.96-96.77)$ & $(71.40-92.95)$ & $(3.03-10.95)$ & $(0.05-0.26)$ & $(73.33-93.49)$ & $(77.33-96.49)$ \\
\hline
\end{tabular}

LR+: Likelihood ratio positive; LR-: Likelihood ratio negative; PPV: Positive predictive value; NPV: Negative predictive value.

Table 3. Comparison of RDW based on mortality

\begin{tabular}{|c|c|c|c|c|c|}
\hline \multirow[t]{2}{*}{ Red cell distribution width } & \multicolumn{2}{|c|}{ Survivors } & \multicolumn{2}{|c|}{ Non-survivors } & \multirow[t]{2}{*}{$\mathbf{p}$} \\
\hline & Mean $\pm S D$ & $\mathbf{n}$ & Mean $\pm S D$ & $\mathbf{n}$ & \\
\hline Day I, $(n=103)$ & $15.2 \pm 1.9 \mid$ & 51 & $17.9 \pm 1.85$ & 52 & $<0.0001$ \\
\hline Day 3, (n=97) & $14.1 \pm 1.69$ & 51 & $17.6 \pm 2.02$ & 46 & $<0.0001$ \\
\hline Day $7,(n=26)$ & $12.9 \pm 1.45$ & 7 & $18.4 \pm 1.13$ & 19 & $<0.0001$ \\
\hline
\end{tabular}

SD: Standard deviation.

$0.35 \mathrm{p}<0.01)$. There were no correlations between RDWI level and Plt count.

\section{DISCUSSION}

Several studies have reported that an increase in RDW is associated with mortality in many diseases including cardiovascular diseases, cancer and general critically ill patients, and as well as in trauma and sepsis. ${ }^{[2,3,5,10,11]}$ In the present study, RDW was found to be an independent predictor of mortality in patients with IAS. In multivariate analysis, only APACHE II and the RDWI independently contributed to the prediction of death.

Although the mechanism of elevated RDW in several conditions is unclear, various studies have mentioned that elevation of RDW in sepsis may be associated with inflammatory processes. Pro-inflammatory cytokines of sepsis such as tumor necrosis factor $\alpha$, interleukin-6, and interleukin-I $B$ could
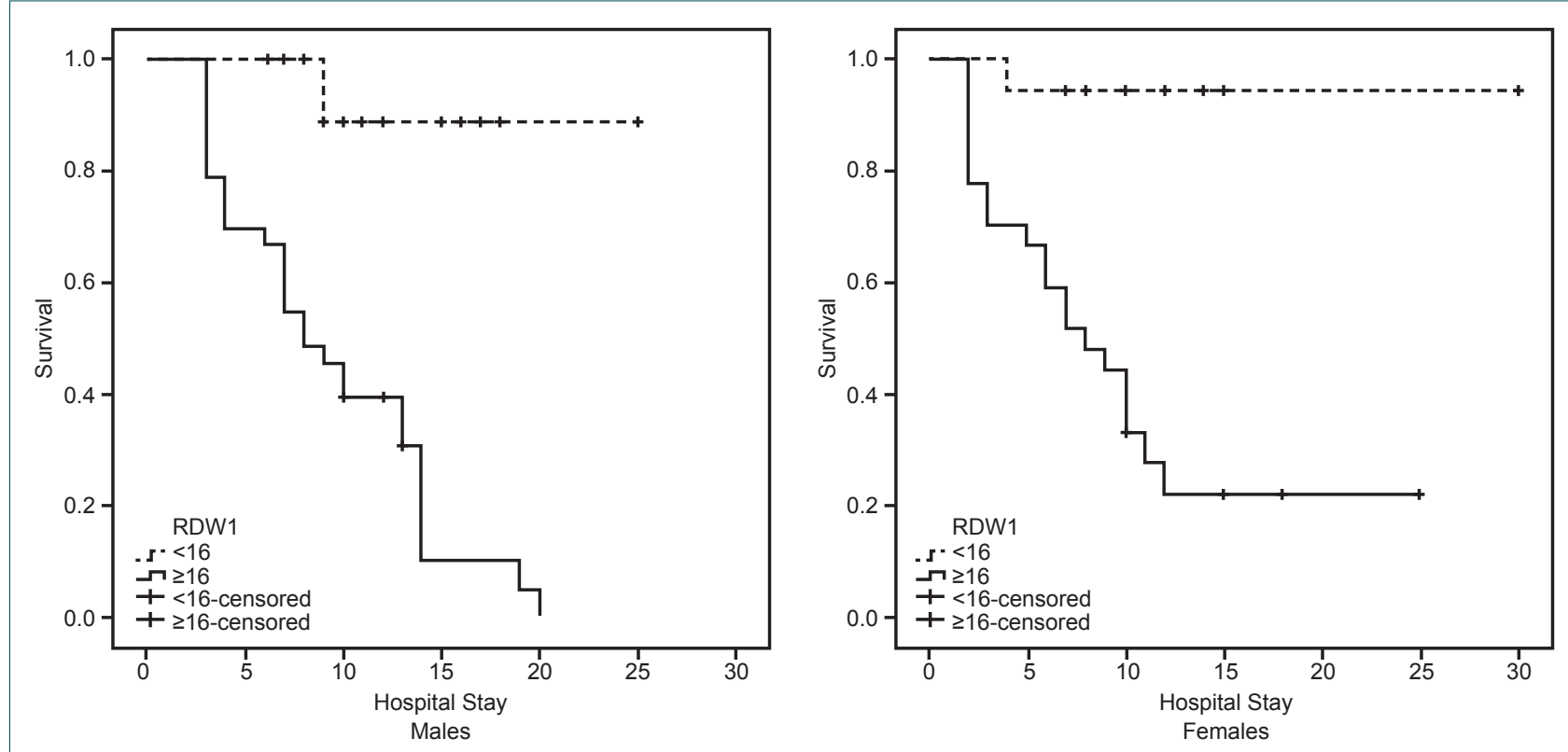

Figure 2. Kaplan-Meier survival curves for hospital mortality among male and female patients. 
suppress RBC maturation, and decrease the half-life of RBC. $[2,6,11]$ The present study showed a positive correlation between RDW and CRP, suggesting that inflammation leads to increased RDW levels. In addition to inflammation, oxidative stress and neurohormonal responses in sepsis might contribute to reduced half-life of RBCs and finally could lead to increased RDW levels. ${ }^{[12]}$

In a very recent multi-centric study, it was found that the most consistent predictors of mortality for patients with peritonitis were increased age, acute renal failure, lower Htc, and hypothermia on ICU admission. ${ }^{[13,14]}$ In the present study, age, source of IAS, presence of comorbidity, RDWI, WBC, APACHE II and CRP were prognostic factors for mortality in univariate analysis. However, RDWI and APACHE II were the only factors effecting mortality in multivariate analysis.

In two recent studies, it was found that adding RDW to APACHE II increased AUC for mortality prediction in ICU patients. $^{[3,1]]}$ Sadaka et al. have also shown that discriminative power of RDW is better than that of APACHE II in ROC analysis in patients with septic shock. ${ }^{\left[{ }^{11]}\right.}$ In our study, ROC curve analysis showed that RDW had a strong discriminative power for mortality in C-IAS patients. In contrast to the study of Sadaka et al., the discriminative power of APACHE II was better than RDW. However, we did not evaluate the effect of adding RDW to APACHE II since the AUCs of both RDW and APACHE II showed strong predictive powers for mortality ( 0.867 for RDWI and 0.943 for APACHE II, respectively).

Increase in RDW from baseline during the first three days in patients with sepsis and septic shock was found to be associated with mortality in a recent study. ${ }^{[15]}$ Our study showed that RDW levels were significantly higher in non-survivors on day three and seven after ICU admission. Therefore, not only RDW on admission, sequential measurements of RDW during ICU stay can also be used as a predictor of mortality. To our knowledge, the present study is the first study investigating the effect of the successive measurements of RDW during the first 7 days on the mortality.

This study has several limitations. First of all, it was conducted at a single institution and is mainly limited by the retrospective nature and the small number of patients. Secondly, RDW could be affected by iron, folate and vitamin BI2, and malnutrition. However, we did not evaluate these variables on admission. Thirdly, primary outcome of the present study was hospital mortality, and our survival analyses considered that patients who were discharged were still alive at later time points. Finally, a possible bias might arise from the fact that all patients in our study population were included from only ICU admissions. There might have been significant differences if we had enrolled all patients with IAS from both ICU and other wards, and the patients who required secondary operations. In addition, the evaluation of pro-inflammatory markers such as interleukin-6, that we did not measure, could lead to investigate the association of inflammation and RDW.

This study shows that increased RDW on admission was significantly associated with mortality in ICU patients with C-IAS. The RDW performed as strong as APACHE II for mortality prediction. Therefore, RDW could be used as a prognostic factor in patients with C-IAS.

\section{Acknowledgements}

There is no source of funding for all authors.

Conflict of interest: None declared.

\section{REFERENCES}

1. Chow AW, Evans GA, Nathens AB, Ball CG, Hansen G, Harding GK, et al. Canadian practice guidelines for surgical intra-abdominal infections. Can J Infect Dis Med Microbiol 2010;21:11-37.

2. Jo YH, Kim K, Lee JH, Kang C, Kim T, Park HM, et al. Red cell distribution width is a prognostic factor in severe sepsis and septic shock. Am J Emerg Med 2013;31:545-8. CrossRef

3. Wang F, Pan W, Pan S, Ge J, Wang S, Chen M. Red cell distribution width as a novel predictor of mortality in ICU patients. Ann Med 2011;43:40-6. CrossRef

4. Zorlu A, Bektasoglu G, Guven FM, Dogan OT, Gucuk E, Ege MR, et al. Usefulness of admission red cell distribution width as a predictor of early mortality in patients with acute pulmonary embolism. Am J Cardiol 2012;109:128-34. CrossRef

5. Majercik S, Fox J, Knight S, Horne BD. Red cell distribution width is predictive of mortality in trauma patients. J Trauma Acute Care Surg 2013;74:1021-6. CrossRef

6. Lippi G, Targher G, Montagnana M, Salvagno GL, Zoppini G, Guidi GC. Relation between red blood cell distribution width and inflammatory biomarkers in a large cohort of unselected outpatients. Arch Pathol Lab Med 2009;133:628-32.

7. Balk RA. Severe sepsis and septic shock. Definitions, epidemiology, and clinical manifestations. Crit Care Clin 2000;16:179-92. CrossRef

8. Levy MM, Fink MP, Marshall JC, Abraham E, Angus D, Cook D, et al. 2001 SCCM/ESICM/ACCP/ATS/SIS International Sepsis Definitions Conference. Crit Care Med 2003;31:1250-6. CrossRef

9. Dellinger RP, Levy MM, Rhodes A, Annane D, Gerlach H, Opal SM, et al. Surviving Sepsis Campaign: international guidelines for management of severe sepsis and septic shock, 2012. Intensive Care Med 2013;39:165-228. CrossRef

10. Anderson JL, Ronnow BS, Horne BD, Carlquist JF, May HT, Bair TL, et al. Usefulness of a complete blood count-derived risk score to predict incident mortality in patients with suspected cardiovascular disease. Am J Cardiol 2007;99:169-74. CrossRef

11. Sadaka F, O'Brien J, Prakash S. Red cell distribution width and outcome in patients with septic shock. J Intensive Care Med 2013;28:307-13.

12. Ghaffari S. Oxidative stress in the regulation of normal and neoplastic hematopoiesis. Antioxid Redox Signal 2008;10:1923-40. CrossRef

13. Tridente A, Clarke GM, Walden A, McKechnie S, Hutton P, Mills GH, et al. Patients with faecal peritonitis admitted to European intensive care units: an epidemiological survey of the GenOSept cohort. Intensive Care Med 2014;40:202-10. CrossRef

14. Eckmann C, Bassetti M. Prognostic factors for mortality in (fecal) perito- 
nitis: back to the roots! Intensive Care Med 2014;40:269-71. CrossRef

15. Kim CH, Park JT, Kim EJ, Han JH, Han JS, Choi JY, et al. An increase in red blood cell distribution width from baseline predicts mortality in patients with severe sepsis or septic shock. Crit Care 2013;17:282. CrossRef

\section{ORIJINAL ÇALIŞMA - ÖZET}

\section{Toplum kökenli karıniçi sepsisli yoğun bakım hastalarında} eritrosit dağılım genişliği değerlerinin mortalite tahminindeki öngörü değeri

Dr. Hatice Kaya Özdoğan, ${ }^{1}$ Dr. Faruk Karateke, ${ }^{2}$ Dr. Sefa Özyazıcı, ${ }^{2}$ Dr. Mehmet Özdoğan, ${ }^{3}$

Dr. Pınar Özaltun, ${ }^{4}$ Dr. Adnan Kuvvetli, ${ }^{2}$ Dr. Cihan Gökler, ${ }^{2}$ Dr. Zeynep Ersoy ${ }^{1}$

${ }^{1}$ Adana Numune Eğitim ve Araştırma Hastanesi, Anestezi ve Reanimasyon Kliniği, Adana

${ }^{2}$ Adana Numune Eğitim ve Araştırma Hastanesi, Genel Cerrahi Kliniği, Adana

${ }^{3}$ Medical Park Adana Hastanesi, Genel Cerrahi Kliniği, Adana

${ }^{4}$ Çukurova Üniversitesi Tıp Fakültesi, Bioistatistik Anabilim Dalı, Adana

AMAÇ: Eritrosit dağııım genişliği (EDG) değeri tam kan sayımının bir parçası olup dolaşımdaki kırmızı kan hücrelerinin dağıııııın değişkenlï̆inin kantitatif bir ölçümüdür. EDG düzeyinin yüksek olması birçok hastalıkta mortalite ile ilişkili olduğu gösterilmiştir. Bu çalışmada yoğun bakımda toplum kökenli intrabdominal sepsis nedeni ile takip ve tedavi edilen hastaların EDG değerleri ile hastane mortalitesi arasındaki ilişki araştırıldı.

GEREÇ VE YÖNTEM: 2010 Ocak-20I3 Mart tarihleri arasında toplum kökenli karıniçi sepsis nedeni ile yoğun bakıma yatan hastaların demografik özellikleri, ek hastalıkları, laboratuvar verileri ve APACHE-II skorları geriye dönük olarak değerlendirildi.

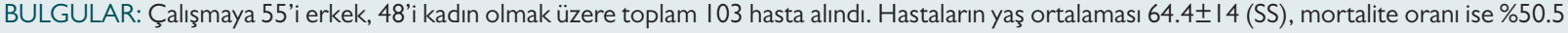
idi. Mortalite olan hastaların yoğun bakıma yatış anındaki ortalama EDG (EDGI) değeri ve APACHE-II skorları mortalite olmayan hastalardan daha yüksek idi. Lojistik regresyon analizinde sadece APACHE-II skoru ve EDGI değerlerinin istatistiksel olarak mortaliteyi etkilediği saptandı. ROC analizinde eğri altında kalan alan EDGI için 0.867 (Güven aralığı: 0.79I-0.942) olarak, APACHE-II için ise 0.943 (Güven aralığı: \%95, 0.902-0.984) olarak saptandı.

TARTIŞMA: Bu çalışmada artmış EDG değerlerinin toplum kökenli karıniçi sepsisli yoğun bakım hastalarında mortalite ile ilişkili olduğu saptanmıştır. Anahtar sözcükler: Mortalite; karıniçi sepsis; peritonit; eritrosit dağılım genişliği; yoğun bakım.

Ulus Travma Acil Cerrahi Derg 2015;2I (5):352-357 doi: 10.5505/tjtes.20I5.26737 